\title{
The effect of protein-deficient isoenergetic diets on the growth of rat jejunal mucosa
}

\author{
BY GABRIELLE SYME \\ Department of Physiology, The University, Sheffield S10 2TN
}

(Received 28 April 1981 - Accepted 17 December 1981)

\begin{abstract}
1. Newly weaned 21 -d-old male rats were given isoenergetic diets containing 200,100 and $50 \mathrm{~g}$ protein $/ \mathrm{kg}$ for $7,14,28$ or $70 \mathrm{~d}$. The mid-jejunum was removed from the rats and a micrometric analysis of the mucosa was made. The following measurements were made: number of villi/ $\mathbf{m m}^{\mathbf{2}}$, villus dimensions, villus surface area, crypt depth, crypt: villus, the number of cells/crypt in metaphase arrest per h.

2. Comparisons were made between animals of the same age but on different diets, and animals on the same diet but of different ages. The latter comparison gave information on the effect of protein deficiency on the pattern of maturation of each feature of the villus or crypt studied.

3. The effect of protein deficiency was not consistent at each stage of maturation. For instance villus height was decreased when compared with the controls following $28 \mathrm{~d}$ on a protein-deficient diet but not after 7 or $70 \mathrm{~d}$.

4. The only measurement to be unaffected by protein deficiency was the number of villi per unit area.

5 . In general the $50 \mathrm{~g}$ protein $/ \mathrm{kg}$ diet had a more pronounced effect than the $100 \mathrm{~g}$ protein $/ \mathrm{kg}$ diet. Protein deficiency delayed maturation by either slowing or inhibiting changes seen in normal maturation.

6. In rats given $50 \mathrm{~g}$ protein $/ \mathrm{kg}$ diet, although the villus surface area did not increase as the rats matured there were increases in epithelial cell production rate and number of crypts per villus.
\end{abstract}

Protein deprivation has been shown to affect villus height or cell turnover or both in the Rhesus monkey (Deo \& Ramalingaswami, 1965; Kumar \& Chase, 1972), the rat (Kern et al. 1966; Hill et al. 1968; Hopper et al. 1972; Subramoniam, 1979) and the human small intestine (Burman, 1965; Stanfield et al. 1965; Brunser, 1977). However, these studies did not compare how the small intestine responded to different levels of protein deficiency, neither did they examine the changes that took place as protein deficiency developed nor make a complete micrometric analysis of the small intestinal mucosa. It was decided, therefore, to examine the effects of two levels of protein deficiency $(100$ or $50 \mathrm{~g} \mathrm{protein} / \mathrm{kg}$ ) on the morphology of jejuna from rats given the diets for 1,4 or 10 weeks from weaning. Micromeasurements were made of the villus and crypt dimensions, the number of crypts and villi per unit area were counted and, using colchicine blockade, epithilial cell production rate was estimated. From these measures the relationship in the control animals between villus surface area and epithelial cell production rate was established so that effects of ageing and protein deficiency could be studied. A preliminary account of part of this work has been given (Husain \& Syme, 1980a).

\section{EX PER I M EN T A L \\ Material and Methods}

Animals. Newly weaned 21-d-old male rats of the Sheffield strain (bred at the University of Sheffield) weighing $30-50 \mathrm{~g}$ were given isoenergetic diets containing 200,100 or $50 \mathrm{~g}$ protein $/ \mathrm{kg}$ for 1,4 or 10 weeks. The diets were made in the laboratory following the formulation recommended by Warner (1962) and were supplemented with $2 \mathrm{~g}$ DLmethionine $/ \mathrm{kg}$. The composition of the basic $200 \mathrm{~g}$ protein $/ \mathrm{kg}$ diet is shown in Table 1 . The protein-deficient diets were made by reducing the protein and adding starch so that the diets were isoenergetic with an energy content of about $16 \mathrm{MJ} / \mathrm{kg}$. Throughout the experiments the animals were allowed free access to drinking-water containing $3 \mu \mathrm{M}$ - 
Table 1. The composition of the control diet $(200 \mathrm{~g}$ protein $/ \mathrm{kg})$

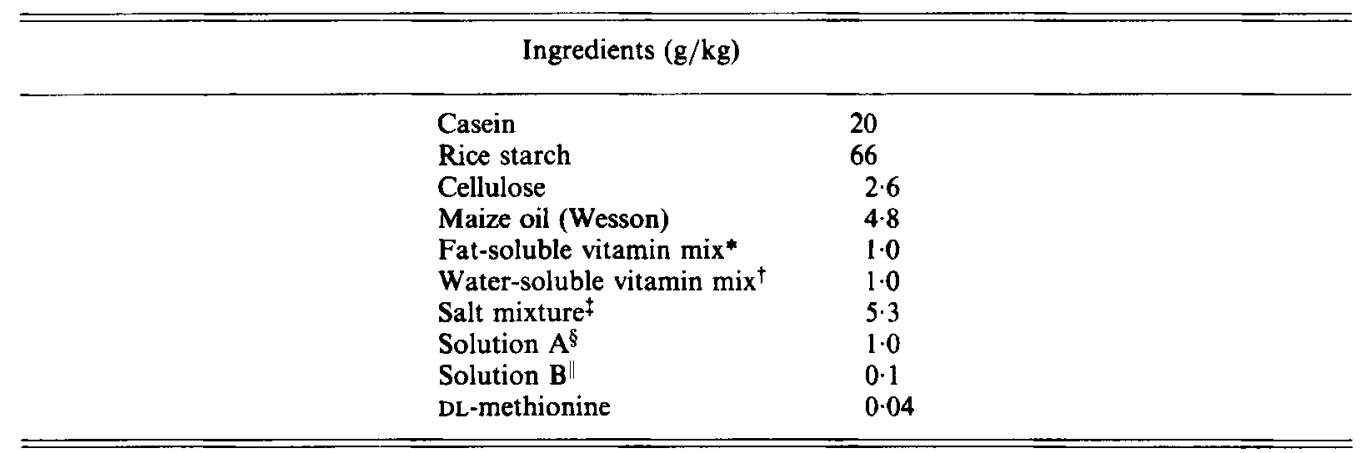

* Contained (mg): vitamin A palmitate 35, cholecalciferol 2, DL- $\alpha$-tocopherylacetate 1200, menaphthone 360 , all mixed with $60 \mathrm{~g}$ maize oil.

+ Contained $(\mathrm{mg})$ : thiamin 120 , riboflavin 120 , pyridoxine 120 , cyanocobalamin $0 \cdot 5$, ascorbic acid 3000 , biotin $5, \beta$-carotene 3 , nicotinic acid 600 , pantothenic acid 360 , choline chloride 6000 , pteroylmonoglutamic acid 40 , myo-inositol 6000 , all mixed with $60 \mathrm{~g}$ cellulose.

‡ Contained (g): $\mathrm{NaCl} 384, \mathrm{CaCO}_{3} 525, \mathrm{MgSO}_{4} .7 \mathrm{H}_{2} \mathrm{O} 168, \mathrm{FeSO}_{4} .7 \mathrm{H}_{2} \mathrm{O} 7 \cdot 5, \mathrm{KH}_{2} \mathrm{PO}_{4} 516$.

$\S$ Contained $(\mathrm{g}): \mathrm{ZnSO}_{4} .7 \mathrm{H}_{2} \mathrm{O} 8 \cdot 7, \mathrm{CuSO}_{4} \cdot 5 \mathrm{H}_{2} \mathrm{O} 1 \cdot 8, \mathrm{MnSO}_{4} \cdot 7 \mathrm{H}_{2} \mathrm{O} 1 \cdot 6$, all dissolved in 11 distilled water.

$\|$ Contained (g): $\mathrm{CoSO}_{4} \cdot 7 \mathrm{H}_{2} \mathrm{O} 2 \cdot 4, \mathrm{Na}_{2} \mathrm{SeO}_{3} 0 \cdot 11,\left(\mathrm{NH}_{4}\right) \mathrm{Mo}_{7} \mathrm{O}_{24} \cdot 4 \mathrm{H}_{2} \mathrm{O} 0 \cdot 9, \mathrm{NaF} 1 \cdot 12$, all dissolved in 11 of distilled water.

potassium iodide. The latter was added to tap-water to compensate for the lack of iodine in the diet.

Confirmation of protein deficiency. The rate of growth and serum albumin levels have been used as indices of protein deficiency.

Eighteen newly weaned 21 -d-old male rats with a mean weight of $45 \pm 1 \mathrm{~g}$ were randomly divided into three groups, each group being assigned to a different diet. Their body-weight was then monitored three times per week for 10 weeks. After 10 weeks the control animals $(200 \mathrm{~g}$ protein $/ \mathrm{kg}$ diet) had reached $322 \pm 21 \mathrm{~g}$, growing at a steady rate of $28 \mathrm{~g} / \mathrm{week}$, whereas animals on $100 \mathrm{~g}$ protein $/ \mathrm{kg}$ gained at only $12 \mathrm{~g} /$ week reaching $170 \pm 14 \mathrm{~g}$. In contrast, the animals on $50 \mathrm{~g}$ protein $/ \mathrm{kg}$ had not grown at all, being $52 \pm 4 \mathrm{~g}$ after 10 weeks on the diet. This retardation or inhibition of growth is a feature of protein deficiency and was used as the criterion for selection of animals for experiments.

Further confirmation of protein deficiency came from serum albumin estimates made on some groups of rats used for the morphometric studies. The dye-binding method of Doumas et al. (1971) was used with rat serum albumin for a standard. The serum albumin levels for the control animals (Table 2) are in the range reported by Coward et al. (1977), who used human serum albumin for the standards. It can be seen from Table 2 that in the instance of animals on $100 \mathrm{~g}$ protein $/ \mathrm{kg}$ diet the serum albumin was not significantly lower than controls until day 28 and remained $23 \%$ below the controls for the rest of the experiment. The serum albumin fell even more rapidly and further in the animals given $50 \mathrm{~g}$ protein $/ \mathrm{kg}$; being significantly lower than the other two groups by day 7 , and by day 28 it had reached a plateau with a value of $27 \%$ below the group given $100 \mathrm{~g}$ protein $/ \mathrm{kg}$ and $42 \%$ below the controls. A depression in serum albumin is one of the most sensitive indices of protein deficiency (Whitehead et al. 1973).

Food intake. This was monitored to check the food intake and therefore energy intake of the three groups of rats. Despite differences in food intake between the three groups, when the mean energy intake for the 4-week period was calculated and then related to body-weight it was found to be very similar. The mean energy intake for the control group 
Table 2. The effects of protein-deficient isoenergetic diets on serum-albumin $(\mathrm{g} / \mathrm{l})$ of rats

(Mean values with their standard errors; nos. of animals given in parentheses)

\begin{tabular}{|c|c|c|c|c|c|c|c|c|}
\hline \multirow{2}{*}{$\begin{array}{l}\text { Period from weaning (d) } \\
\text { Group }\end{array}$} & \multicolumn{2}{|c|}{$\mathbf{0}$} & \multicolumn{2}{|c|}{7} & \multicolumn{2}{|c|}{28} & \multicolumn{2}{|c|}{70} \\
\hline & Mean & $\mathbf{S E}$ & Mean & SE & Mean & SE & Mean & $\mathbf{S E}$ \\
\hline Weaned 21-d-old rats & $38 \cdot 36$ & 1.43 & & & & & & \\
\hline $200 \mathrm{~g}$ protein $/ \mathrm{kg}$ diet & & & $39 \cdot 42$ & $3 \cdot 16$ & $42 \cdot 84$ & 0.72 & $43 \cdot 39$ & $0 \cdot 10$ \\
\hline $100 \mathrm{~g}$ protein $/ \mathrm{kg}$ diet & & & 37.83 & 1.83 & $33.45^{*}$ & $2 \cdot 72$ & 33.93 & 1.69 \\
\hline $50 \mathrm{~g}$ protein $/ \mathrm{kg}$ diet & & & $34 \cdot 54$ & 0.93 & $24.25 *$ & 1.61 & $24 \cdot 56$ & 0.11 \\
\hline
\end{tabular}

* Values for experimental group were statistically significantly different from those for $200 \mathrm{~g}$ protein $/ \mathrm{kg}$ diet group.

$\dagger$ Values for $50 \mathrm{~g}$ protein $/ \mathrm{kg}$ diet group were statistically significantly different from those for $100 \mathrm{~g}$ protein $/ \mathrm{kg}$ diet group.

was $0.99 \mathrm{MJ} / \mathrm{kg}$ body-weight ${ }^{0.73}$ per rat per $\mathrm{d}$ compared with $1.17 \mathrm{MJ} / \mathrm{kg}$ body-weight ${ }^{0.73}$ per rat per $\mathrm{d}$ for the $100 \mathrm{~g}$ protein $/ \mathrm{kg}$ diet animals and $0.81 \mathrm{MJ} / \mathrm{kg}$ body-weight ${ }^{0.73}$ per rat per $\mathrm{d}$ for the $50 \mathrm{~g}$ protein $/ \mathrm{kg}$ diet animals. These values are in good agreement with previous studies (Stead \& Brock, 1972; Heard et al. 1977).

Morphometric analysis. The problem of selection of representative samples of crypts and villi has been discussed by Clarke (1973). His techniques have been adhered to closely throughout to ensure no bias towards particular shapes or sizes of villi, and the coefficient of variation has been in the order of $10 \%$, in agreement with Clarke (1973).

The variation in group size seen in all these experiments reflects the fact that it was not possible to obtain results from all the animals initially placed on the three diets. Reasons for this were death of animals before they reached the appropriate age for the study and loss of tissue, particularly from the protein-deficient animals. Sometimes the fixed tissue was so soft that microdissection could not be performed. The softness probably reflected the thinning of the small intestine in protein deficiency.

Number of villi/ $\mathrm{mm}^{2}$. The animals were anaesthetized with an intraperitoneal injection of Sagatal $(1.5 \mathrm{ml}$ sodium pentobarbitone $(60 \mathrm{mg} / \mathrm{ml}) / \mathrm{kg}$ body-weight $)$. A piece of midjejunum, $45 \mathrm{~mm}$ long, was removed and fixed in formal saline ( $9 \mathrm{~g}$ sodium chloride/1) for $24 \mathrm{~h}$. It was then transferred to ethanol $(750 \mathrm{ml} / 1)$ for at least $24 \mathrm{~h}$ or until observations were made. A $10 \mathrm{~mm}$ piece of this tissue was split longitudinally along the mesenteric border and pinned, mucosal surface upwards, on to dental wax. A technique developed by R. D. E. Rumsey (personal communication) was then used to made the quantifying and microdissection of the villi easy. The tissue was washed for two 10 min periods in ethanol $(500 \mathrm{ml} / 1)$ and distilled water respectively, and then dipped into an osmium tetroxide solution $(1 \mathrm{~g} / \mathrm{l})$ for a few minutes until a brownish tinge appeared. Following further washing in distilled water approximately $30 \mathrm{~mm}^{2}$ of the tissue was photographed using a photomicroscope. From each photograph of a piece of small intestine eight separate estimates of the number of villi $/ \mathrm{mm}^{2}$ were made.

Villus dimensions. After photographing the tissue, the villi were microdissected and then, using a microscope, the shape of the villus was noted and the calibrated micrometer eyepiece enabled three measurements to be made. These were (1) the width of the base of the villus, 


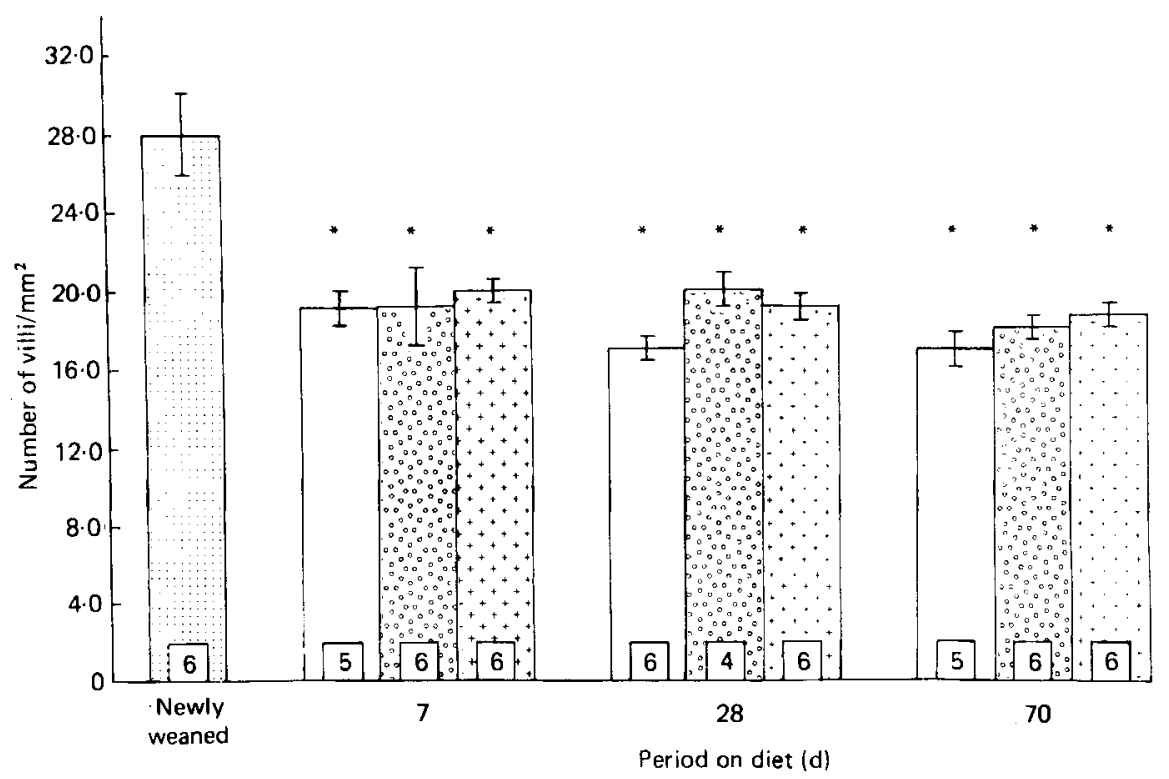

Fig. 1. The number of villi $/ \mathrm{mm}^{2}$ of rat mid-jejunum following 7,28 or $70 \mathrm{~d}$ on protein-deficient isoenergetic diets containing $50(\square), 100(\because)$ or $200(\square)$ g protein $/ \mathrm{kg}$. Values are means with their standard errors represented by vertical bars; nos. of animals given in the boxes.

* Values were significantly different from those for the newly weaned group.

(2) the height of the villus, (3) the width of the apex $0.08 \mathrm{~mm}$ away from the tip of the villus. These measurements were made on twenty villi from each piece of small intestine.

Using graph paper, scale drawings were made of each villus and the surface area of one face derived by planimetry. This value was then doubled to give the total surface area of the villus. Although the assumption that the villus is flat is incorrect it has been accepted as a constant small error throughout the study.

Crypt: villus. Once the villi had been dissected from the piece of small intestine, the crypts could be seen underneath. The number of crypts $/ \mathrm{mm}^{2}$ was calculated and then related to the number of villi $/ \mathrm{mm}^{2}$ in the same piece of tissue. The mean value for each animal was obtained from eight measurements.

Colchicine-metaphase accumulation rate. Rats were injected intraperitoneally with a freshly prepared solution of colchicine $(1 \mathrm{mg} / \mathrm{kg}$ body-weight) in saline solution. The period of time between injecting the colchicine and anaesthetizing the rats with diethyl ether was determined accurately, and was as close to $2 \mathrm{~h}$ as possible. The whole small intestine was fixed as described by Clarke (1970) and crypt of Leiberkühn squashes prepared from 10-20 mm pieces of mid-jejunum as described by Wimber \& Lamberton (1963). The number of colchicine-metaphases was counted in twenty crypts per animal and the depth of ten crypts per animal measured.

Expression of results. Results are expressed as the mean values with their standard errors. Comparisons were made between groups of animals on the same diets but of different ages and between animals on different diets but of the same age. For each comparison an analysis of variance was used to indicate whether there were differences, and the least-significant range test used to locate the significant differences (Sokal \& Rohlf, 1969). The test was applied at the $P=0.05$ level, therefore differences described as significant will be at this level. 


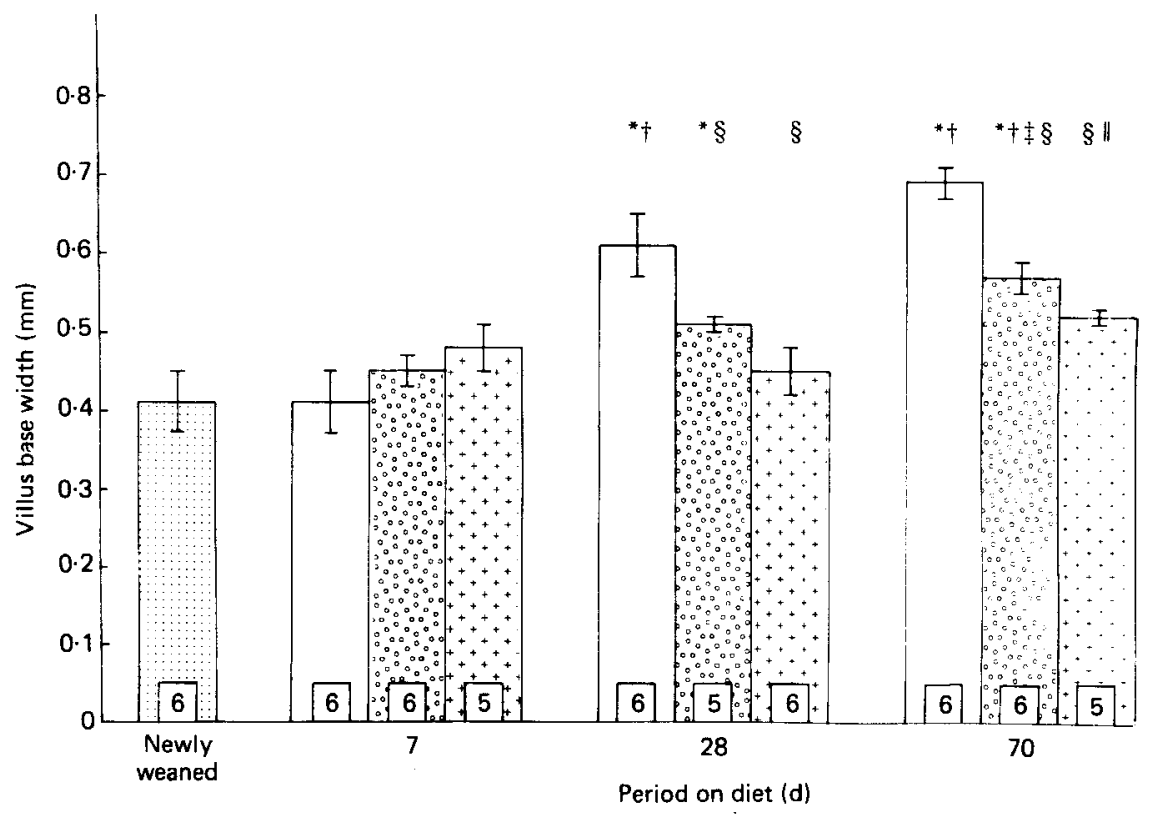

Fig. 2. The villus base width following 7,28 or $70 \mathrm{~d}$ on protein-deficient isoenergetic diets containing $50(+.7), 100($ ( 5 . by vertical bars; nos. of animals given in the boxes.

* Values were significantly different from those for the newly weaned group.

$\dagger$ Values were significantly different from $7 \mathrm{~d}$ on the same diet.

$\ddagger$ Values were significantly different from $28 \mathrm{~d}$ on the same diet.

$\S$ Values were significantly different from those for rats of the same age given $200 \mathrm{~g}$ protein $/ \mathrm{kg}$ diet.

|| Values were significantly different from those for rats of the same age given $100 \mathrm{~g}$ protein $/ \mathrm{kg}$ diet.

\section{RESULTS}

There are many comparisons that could be made, since the effect of three different diets on eight criteria at four different ages has been studied. However, this study has focused on the normal pattern of maturation of the crypts and villi and the effect of protein-deficient isoenergetic diets on this. Rather than discuss each relevant comparison all the results have been presented as grouped histograms (Figs. 1-8) with any significant differences indicated, and the trends have been highlighted in the text.

\section{Number of villi/ $\mathrm{mm}^{2}$}

In all three groups of animals (Fig.1) the number of villi $/ \mathrm{mm}^{2}$ of mid-jejunum fell significantly on weaning. There were then no further changes of significance as the animals aged; thus protein deficiency did not significantly affect the normal pattern of development and no significant difference was found between animals of the same age but on a different diet.

\section{Villus measurements}

Base width. The results are shown in Fig. 2. In the control animals the villus base width was identical at weaning and 1 week later but it then increased by $58 \%$ to a plateau. Villi from animals given $100 \mathrm{~g}$ protein $/ \mathrm{kg}$ diet also increased in base width but the increase was smaller, more gradual and continued longer. Thus a plateau was not reached, and on both 


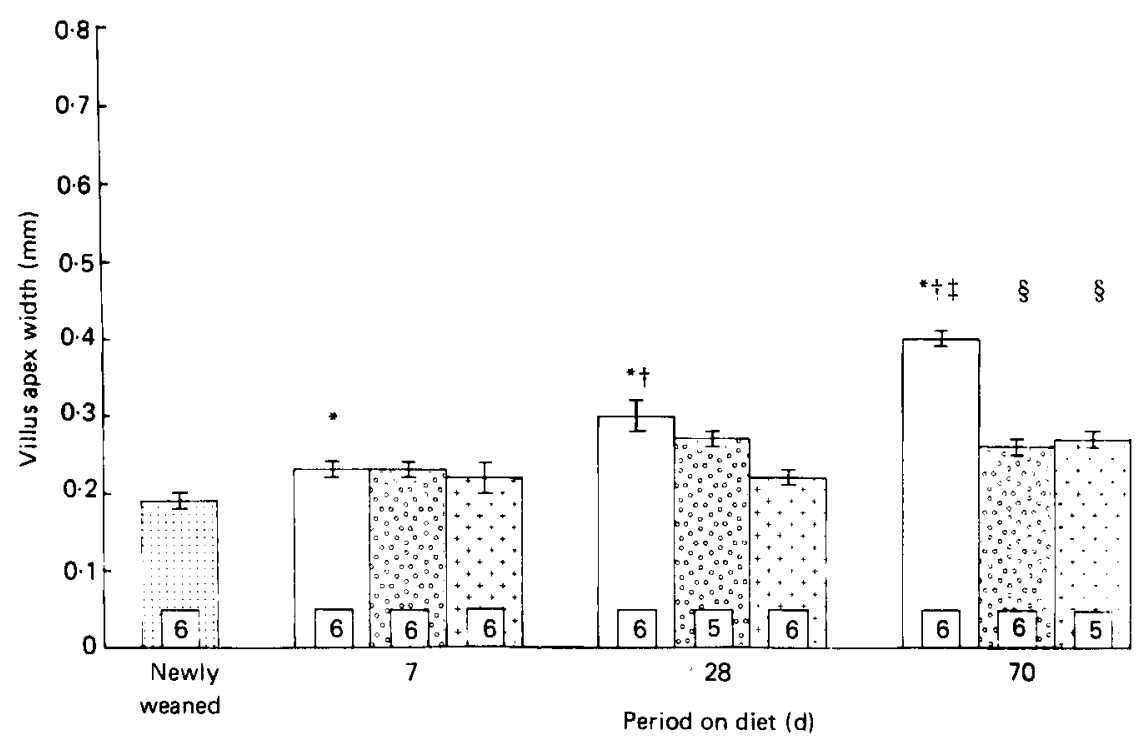

Fig. 3. The villus apex width following 7, 28 or $70 \mathrm{~d}$ on protein-deficient isoenergetic diets containing $50(\square), 100$ ( $\square$ ( $\square$ ) or $200(\square)$ g protein $/ \mathrm{kg}$. Values are means with their standard errors represented by vertical bars; nos. of animals given in the boxes.

* Values were significantly different from those for the newly weaned group.

$\dagger$ Values were significantly different from $7 \mathrm{~d}$ on the same diet.

$\ddagger$ Values were significantly different from $28 \mathrm{~d}$ on the same diet.

$\S$ Values were significantly different from those for rats of the same age given $200 \mathrm{~g}$ protein $/ \mathrm{kg} \mathrm{diet}$.

day 28 and day 70 the base width was significantly less than for controls of the same age. This suggests a delay in maturation. As the protein content decreased even further no significant change in villus base width occurred with ageing. This suggests total inhibition of maturation has occurred.

Apex width. In the normal animals maturation resulted in a progressive increase in villi apex width, such that the increase was significant between each point of measurement (Fig. 3). Reducing the diet to 100 or $50 \mathrm{~g}$ protein $/ \mathrm{kg}$ prevented this increase in apex width with ageing, so that by day 70 the apex width was significantly less in both experimental groups than in the control animals of the same age.

Villus height. After no significant change in the first $7 \mathrm{~d}$, villus height increased $38 \%$ between day 7 and day 28 and then decreased by $20 \%$ in the final period of study (Fig. 4). As with other measurements, in the animals given $100 \mathrm{~g}$ protein $/ \mathrm{kg}$ diet the changes that occurred were smaller, thus the increase between day 7 and day 28 was only $27 \%$. Instead of a decrease between day 28 and day 70 , as in the controls, there was no further change. The height of villi from animals given $50 \mathrm{~g}$ protein $/ \mathrm{kg}$ diet did not alter at all as the animals matured. It is important to note that only at day 28 did protein deficiency result in a reduced villus height compared to control animals of the same age.

Surface area. As might be predicted, the changes in the individual dimensions of the villi result in changes in mean surface area. It can be seen from Fig. 5 that in the control animals the mean surface area did not increase in the first $7 \mathbf{d}$ but then increased approximately $109 \%$ to a plateau between day 28 and day 70 . The mean surface area of villi from animals given $100 \mathrm{~g}$ protein $/ \mathrm{kg}$ diet also increased to a plateau between day 28 and day 70 . However, there was only a $79 \%$ increase above the newly weaned value. In contrast, the mean surface 


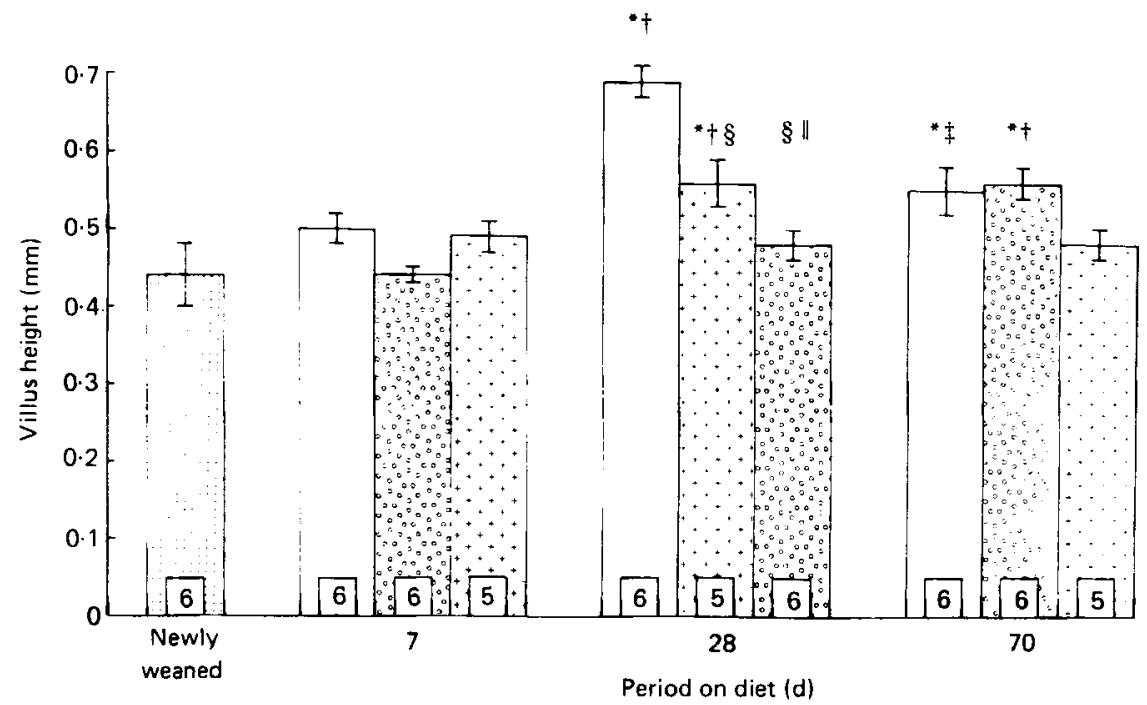

Fig. 4. The villus height following 7,28 or $70 \mathrm{~d}$ on protein-deficient isoenergetic diets containing $50(\square), 100(\square)$ or $200(\square) \mathrm{g}$ protein $/ \mathrm{kg}$. Values are means with their strandard errors represented by vertical bars; nos. of animals given in the boxes.

* Values were significantly different from those for the newly weaned group.

$\dagger$ Values were significantly different from $7 \mathrm{~d}$ on the same diet.

$\ddagger$ Values were significantly different from $28 \mathrm{~d}$ on the same diet.

$\S$ Values were significantly different from those for rats of the same age given $200 \mathrm{~g}$ protein $/ \mathrm{kg}$ diet.

|f Values were significantly different from those for rats of the same age given $100 \mathrm{~g}$ protein $/ \mathrm{kg}$ diet.

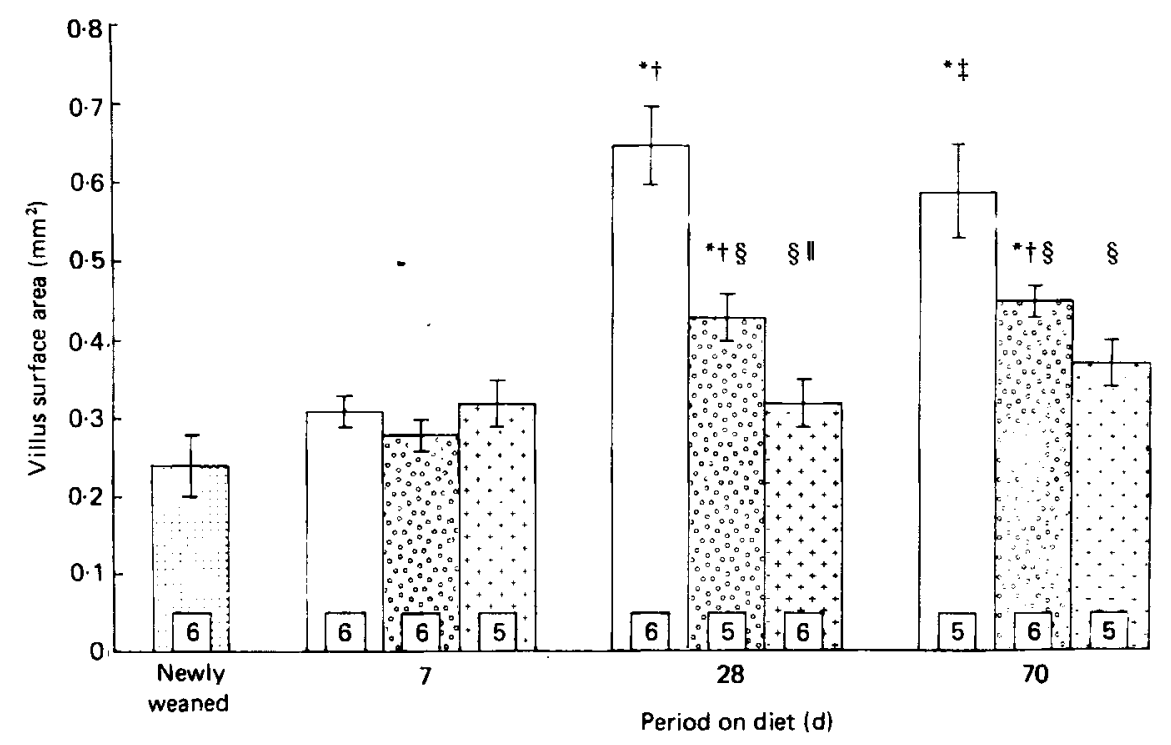

Fig. 5. The mean villus surface area following 7,28 or $70 \mathrm{~d}$ on protein-deficient isoenergetic diets

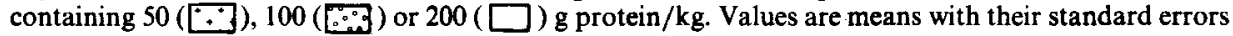
represented by vertical bars; nos. of animals given in the boxes.

* Values were significantly different from those for the newly weaned group.

+ Values were significantly different from $7 \mathrm{~d}$ on the same diet.

$\S$ Values were significantly different from those for rats of the same age given $200 \mathrm{~g}$ protein $/ \mathrm{kg}$ diet.

$\|$ Values were significantly different from those for rats of the same age given $100 \mathrm{~g}$ protein $/ \mathrm{kg}$ diet. 


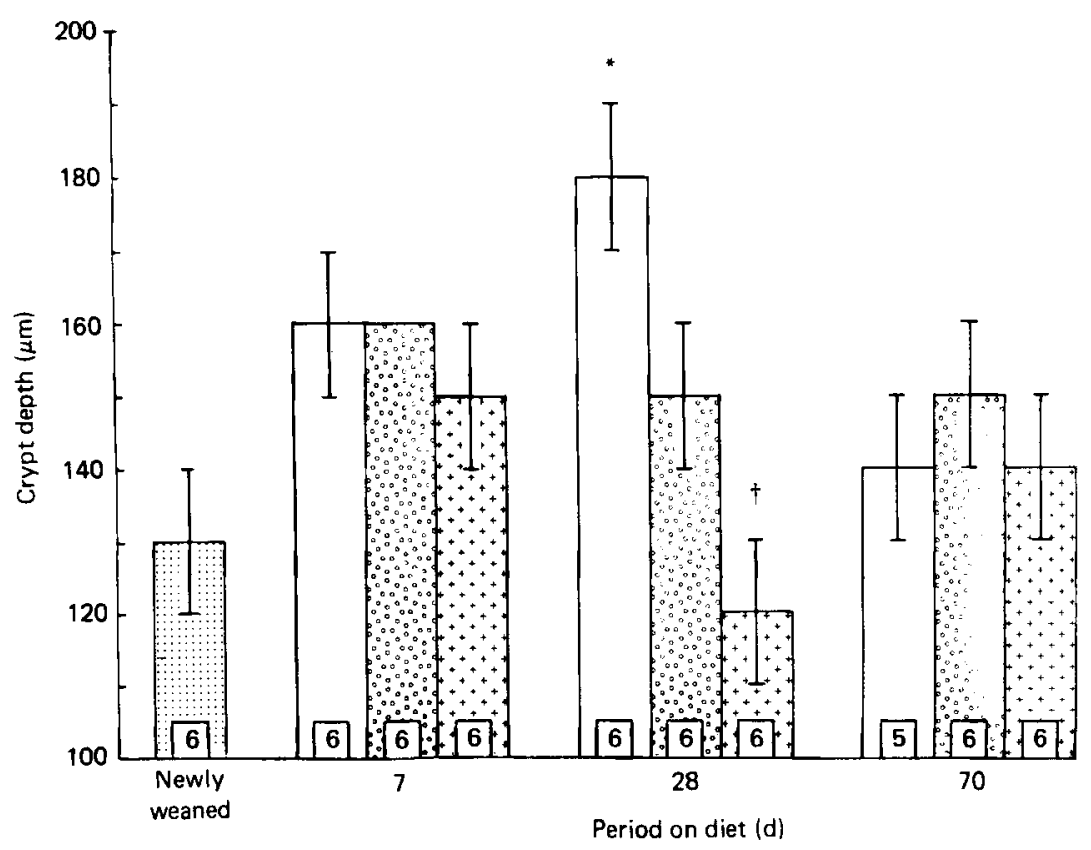

Fig. 6. The crypt depth following 7,28 or $70 \mathrm{~d}$ on protein-deficient isoenergetic diets containing $50([+\square), 100$ ( represented by vertical bars; nos. of animals given in the boxes.

* Values were significantly different from those for the newly weaned group.

$\dagger$ Values were significantly different from $7 \mathrm{~d}$ on the same diet.

area of villi from animals given $50 \mathrm{~g}$ protein $/ \mathrm{kg}$ diet did not change significantly. As a result on day 28 and day 70 there were marked differences between the mean surface area of villi from the three dietary groups; but on day 7 no such difference was observed.

\section{Crypt dimensions}

Crypt depth. Only modest changes in crypt depth were observed. The crypt depth increased $38 \%$ between weaning and $28 \mathrm{~d}$ later and then decreased $23 \%$ from day 28 to day 70 (Fig.6). However, only at day 28 was the crypt depth significantly different from that of newly weaned rats. Both levels of protein deficiency affected the pattern of maturation of the crypts similarly, the crypt depth not increasing as the animals aged.

Crypt: villus. In the control group crypt:villus increased throughout the period of study, the over-all increase being $95 \%$. All values were significantly different from the newly weaned group and from each other (Fig. 7). The over-all increase of $90 \%$ in the animals given $100 \mathrm{~g}$ protein $/ \mathrm{kg}$ diet was almost as large, with all values being significantly different from the newly weaned group. Even at the lowest protein intake crypt:villus increased, though the over-all increase of $53 \%$ was smaller. However, the pattern of maturation of crypt:villus was very different in animals given $50 \mathrm{~g}$ protein $/ \mathrm{kg}$ diet, with increases between weaning and day 7 and day 28 and day 70 but a decrease between day 7 and day 28. The smaller over-all increases in crypt:villus for rats given $50 \mathrm{~g}$ protein $/ \mathrm{kg}$ diet resulted in significant differences in this value when compared with the controls or those given $100 \mathrm{~g}$ protein $/ \mathrm{kg}$ diet at days 28 and 70 .

Colchicine-metaphases/crypt per $h$. For all factors measured the most pronounced changes with ageing were found in the control animals, and this was again the situation 


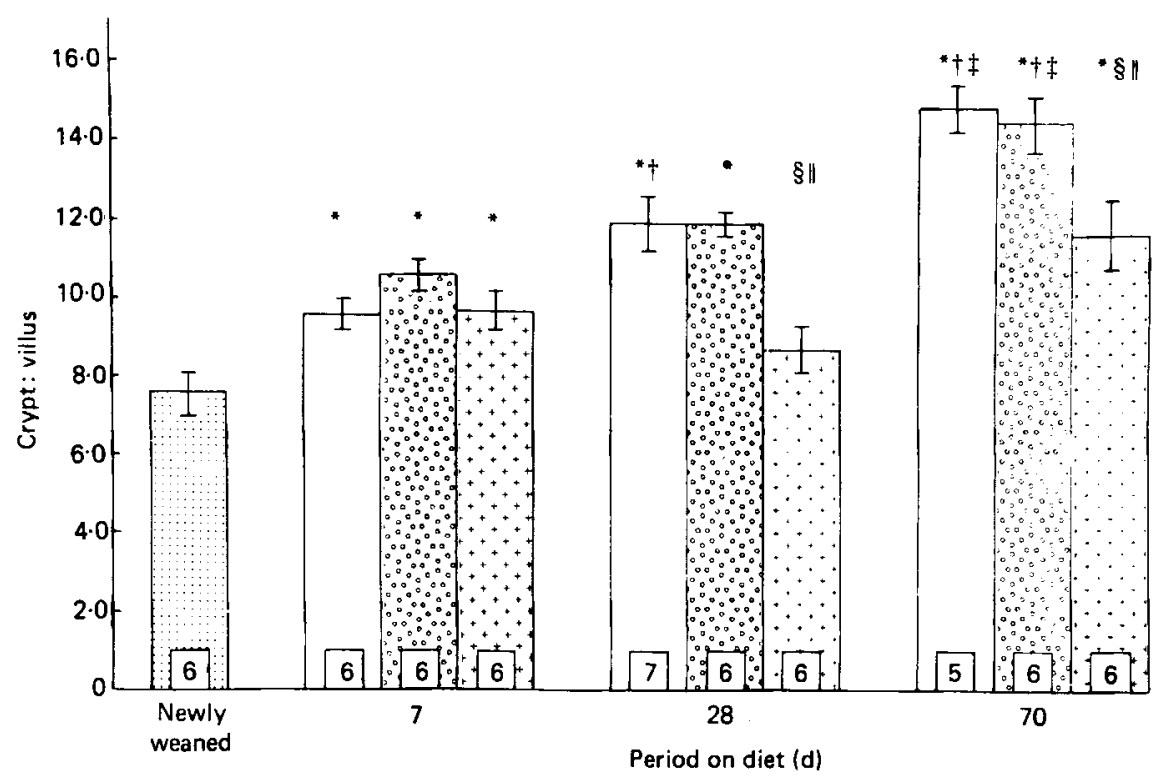

Fig. 7. Crypt:villus following 7, 28 or $70 \mathrm{~d}$ on protein-deficient isoenergetic diets containing $50(\square), 100(\square)$ or $200(\square) g$ protein $/ \mathrm{kg}$. Values are means with their standard errors represented by vertical bars; nos. of animals given in the boxes.

* Values were significantly different from those for the newly weaned group.

$\dagger$ Values were significantly different from $7 \mathrm{~d}$ on the same diet.

$\$$ Values were significantly different from $28 \mathrm{~d}$ on the same diet.

$\S$ Values were significantly different from those for rats of the same age given $200 \mathrm{~g}$ protein $/ \mathrm{kg}$ diet.

\| Values were significantly different from those for rats of the same age given $100 \mathrm{~g}$ protein $/ \mathrm{kg}$ diet.

(Fig. 8). The number of cells/crypt in metaphase arrest per $\mathrm{h}$ increased significantly both from weaning to day 7 and from day 7 to day 28 , and then decreased significantly by day 70. In the control group all values were significantly different from each other and from the newly weaned animals. A similar trend but with smaller increases and decreases was also seen in the rats given $100 \mathrm{~g}$ protein $/ \mathrm{kg}$ diet. In the instance of animals given $50 \mathrm{~g}$ protein $/ \mathrm{kg}$ diet the number of cells in metaphase arrest increased still more slowly, and unlike the other two groups did not decrease between days 28 and 70 . The result of the smaller changes in both groups of protein-deficient animals was that at day 7 and day 28 the number of crypts in metaphase arrest was significantly less than for the controls of the same age. However, this was not true at day 70 , where there was no significant difference between the three groups.

\section{DISCUSSION}

Many measurements have been made in this study, but those of particular interest were surface area and epithelial cell production rate. The former because of its importance functionally and the latter because any changes in villus architecture might be expected to be related to epithelial cell production rate.

The normal pattern of development of the mid-jejunal villus and crypt is seen in the rats given $200 \mathrm{~g}$ protein $/ \mathrm{kg}$ diet. The villus surface area increased between weaning and day 28 as did villus height, crypt depth, the number of crypts/villus and the number of cells in colchicine-metaphase arrest (epithelial cell production rate). However, between days 28 and 70 , whereas the villus surface area was unchanged, the number of cells in colchicine- 


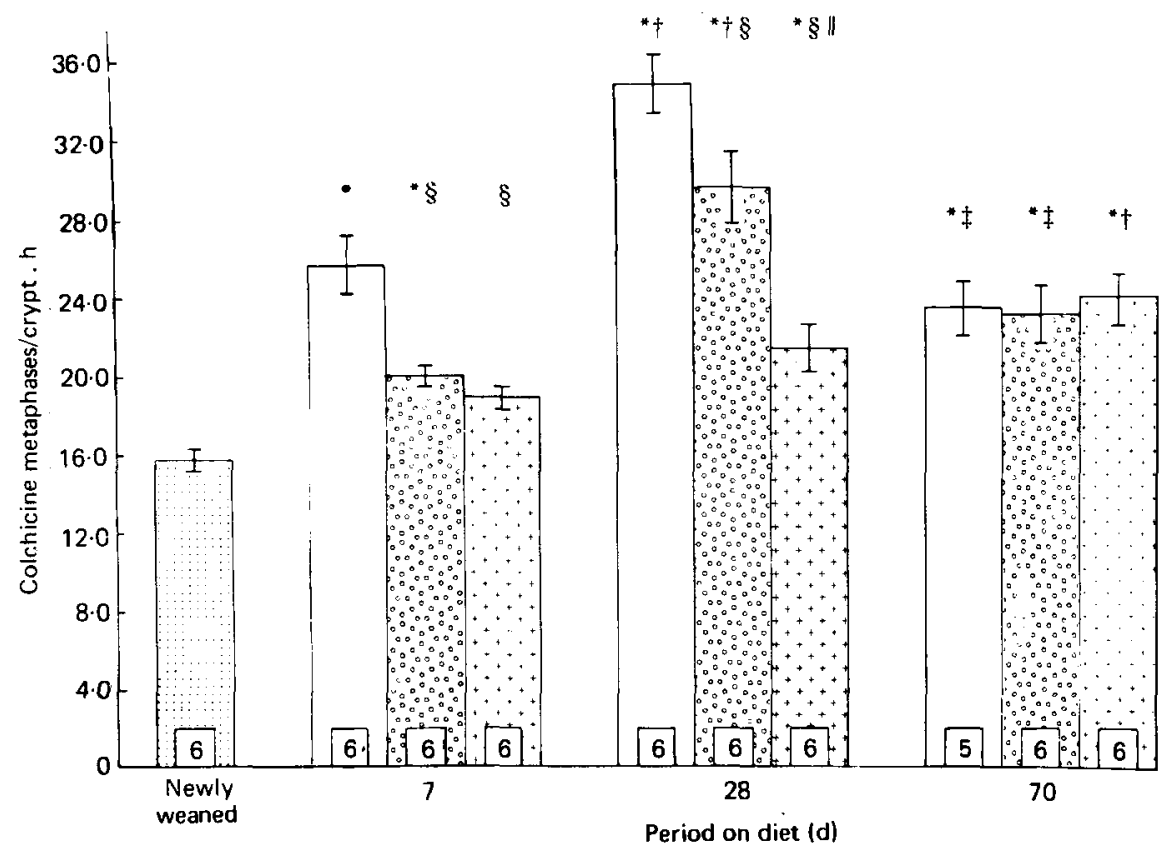

Fig. 8. The number of cells in colchicine metaphase arrest/crypt per h following 7,28 or $70 \mathrm{~d}$ on protein-deficient isoenergetic diets containing $50([+]), 100(\underset{0}{+})$ or $200(\square) \mathrm{g}$ protein/kg. Values are means with their standard errors represented by vertical bars; nos. of animals given in the boxes.

* Values were significantly different from those for the newly weaned group.

$\dagger$ Values were significantly different from $7 \mathrm{~d}$ on the same diet.

$\$$ Values were significantly different from $28 \mathrm{~d}$ on the same diet.

$\S$ Values were significantly different from those for rats of the same age given $200 \mathrm{~g}$ protein $/ \mathrm{kg}$ diet.

"Values were significantly different from those for rats of the same age given $100 \mathrm{~g}$ protein $/ \mathrm{kg}$ diet.

metaphase arrest, crypt depth and villus height decreased and the number of crypts/villus increased. These observations illustrate two points. First, as Clarke (1974) observed, villus height is not a good index of villus surface area; for although the villus height decreased between days 28 and 70 this was matched by an increase in apex width, so the villus surface area did not change. Secondly, as observed by Kapadia \& Baker (1976), changes in surface area and colchicine-metaphase arrest may not mirror one another; although in the control animals changes in the number of cells in colchicine-metaphase arrest were mirrored by changes in villus height. This is in agreement with Clarke (1977).

Other workers have also studied maturation of the small intestine of normal fed rats (Clarke, 1972, 1977; Kapadia \& Baker, 1976). Although these previous studies conflict in points of detail with one another and with the results presented here, quantitatively they are very similar; confirmation of our techniques. The reasons for the discrepancies are likely to be because no two studies are strictly comparable. Factors such as different strains of rats, different diets, slightly different areas of the small intestine, different timings, age of weaning, sex and whether animals were selected on an age basis (Kapadia \& Baker, 1976) or a weight basis (Clarke, 1977) make no two studies identical.

Two levels of protein deficiency were investigated; $100 \mathrm{~g}$ protein $/ \mathrm{kg}$ diet, which was adequate to allow growth but not enough for the animal to reach its full genetic potential for growth; and $50 \mathrm{~g}$ protein $/ \mathrm{kg}$ diet, which was inadequate for any growth to occur. The effects of the two diets on villus morphology were similarly graded; with the pattern of 
changes being similar but smaller compared to the controls in rats given $100 \mathrm{~g}$ protein $/ \mathrm{kg}$ diet and even smaller or totally inhibited in the animals given $50 \mathrm{~g}$ protein $/ \mathrm{kg}$ diet. Thus villus height, villus surface area and the number of cells in colchicine-metaphase arrest increased between weaning and $28 \mathrm{~d}$ by 57,170 and $122 \%$ respectively for the controls, by 27,79 and $89 \%$ for the rats given $100 \mathrm{~g}$ protein $/ \mathrm{kg}$ diet and 9,18 (both insignificant) and $36 \%$ for the low protein intake rats. There were two exceptions to this observation that the effects of the protein deficiency were graded depending on the extent of the deficiency. First, the number of villi $/ \mathrm{mm}^{2}$ was unaffected by either level of protein deficiency: Clarke (1972) found that fasting rats for $5 \mathrm{~d}$ also had no effect on number of villi $/ \mathrm{mm}^{2}$. Secondly, the number of crypts/villus was only affected significantly by severe protein deficiency, the crypt:villus increasing only $53 \%$ between weaning and $70 \mathrm{~d}$ in the animals given $50 \mathrm{~g}$ protein $/ \mathrm{kg}$ diet compared with $82 \%$ for the controls and $76 \%$ for the animals given $100 \mathrm{~g}$ protein $/ \mathrm{kg}$ diet.

Previous studies on the effects of experimental protein deficiency in rats and monkeys and protein deficiency diseases in humans have observed: a decrease in villus height (Deo \& Ramalingaswami, 1965; Stanfield et al. 1965; Kern et al. 1966; Brunser, 1977; Subramoniam, 1979), though Hill et al. (1968) observed that villus length was only minimally affected; a decrease in crypt depth (Deo \& Ramalingaswami, 1965; Stanfield et al. 1965; Kumar \& Chase, 1972); and a slower transit time of epithelial cells up the villus ( Deo \& Ramalingaswami, 1965; Hopper et al. 1972). At some points in the present study protein deficiency has been shown to decrease villus height, crypt depth and crypt:villus of rat mid-jejunum. However, none of these studies, even those on rats, is directly comparable with the present investigations. First because Kern et al. (1966) and Hill et al. (1968) used protein-free diets and Subramoniam (1979) induced malnutrition by causing maternal protein deficiency, whereas this study used isoenergetic diets containing 50 or $100 \mathrm{~g}$ protein $/ \mathrm{kg}$. Secondly, the use of a longitudinal study gives over-all information on the pattern of maturation which cannot be derived from examining only one time-period. The choice of time-period is also critical. For instance, a decreased villus height as a result of protein deficiency was observed $28 \mathrm{~d}$ after weaning but not 7 or $70 \mathrm{~d}$ after weaning. What this longitudinal study does show is that protein deficiency either slows or inhibits maturation, depending on the factor and the extent of the deficiency. The maturation of the villus in terms of height and surface area was slowed by $100 \mathrm{~g}$ protein $/ \mathrm{kg}$ diet and inhibited by $50 \mathrm{~g}$ protein $/ \mathrm{kg}$ diet. The maturation of the crypt in terms of crypt depth was inhibited by both levels of protein deficiency, in terms of crypt: villus was slowed only by the lower level of protein deficiency, and in terms of epithelial cell production rate was reduced by both levels of deficiency, but the effect was more pronounced with the $50 \mathrm{~g}$ protein $/ \mathrm{kg}$ diet. The result of each level of protein deficiency inhibiting the maturation of some factors and slowing of others is that the balance between epithelial cell production rate and the distribution of cells between the villus and crypt compartments may alter. This change of balance is unlikely to be unique to protein deficiency, and would explain why in normal maturation as well as protein deficiency one cannot assume that changes in epithelial cell production rate will be reflected simply in changes in either villus height or surface area.

Functionally the alterations in surface area of the villus will be important. In the more severe protein deficiency the surface area does not increase at all over the $70 \mathrm{~d}$ of this study although the epithelial cell production rate does increase, albeit less than the controls. The only other factor to increase is the crypt: villus, suggesting the morphological response to severe protein deficiency is an increased production of crypts of Lieberkühn. In this context it is perhaps interesting to compare these results with malnutrition in human adults and children. The condition of these rats resembles marasmus more closely both in the physical 
symptoms and in the changes in small intestinal morphology (Brunser, 1977). In marasmus, as in this study, the villi shorten but their number does not change, whereas in kwashiorkor the villi again shorten but their number decreases owing to fusion so that ridge or leaf-shaped villi are common (Burman, 1965; Stanfield et al. 1965). As a consequence the crypt:villus increases in both conditions although in protein-deficient rats the crypt number has increased whereas in kwashiorkor the villus number has decreased.

Finally it is interesting to consider whether these dietary-induced changes in mucosal morphology are designed to preserve intestinal function under conditions where the intake of protein is limiting to growth or whether they merely represent a passive response to a change in diet. Some evidence for the former view comes from the finding that valine absorption, related to total mg DNA, is actively increased in these protein-deficient rats (Husain \& Syme, 1980 b). Recent work has shown that not only is epithelial cell production rate reduced but also the rate of migration (Syme \& Smith, 1982). This allows individual cells time to express fully their capacity to absorb nutrients even though individual villi are reduced in height. Future study will be designed to study this aspect of adaptation.

The author thanks Sheffield University Medical Research Fund for financing the purchase of diet ingredients and Miss Bernadette Wainwright for her expert technical assistance.

\section{REFERENCES}

Brunser, O. (1977) Clin. Gastroenterology 6, 341.

Burman, D. (1965). Archs Dis. Childh. 40, 526.

Clarke, R. M. (1970). J. Anat. 107, 519.

Clarke, R. M. (1972). J. Anat. 112, 27.

Clarke, R. M. (1973). Digestion 8, 161.

Clarke, R. M. (1974). In Intestinal Adaptation, p. 11 [R. H. Dowling and E. O. Riecken, editors]. Stuttgart:

F. K. Schattauer Verlag.

Clarke, R. M. (1977). J. Anat. 123, 805.

Coward, W. A., Whitehead, R. G. \& Lunn, P. G. (1977). Br. J. Nutr. 38, 115.

Deo, M. G. \& Ramalingaswami, V. (1965). Gastroenterology 49, 150.

Doumas, B. T., Watson, W. \& Biggs, H. G. (1971). Clinica chim. Acta 31, 87.

Heard, C. R. C., Frangi, S. M., Wright, P. M. \& McCartney, P. R. (1977). Br. J. Nutr. $37,1$.

Hill, R. B., Prosper, J., Hirschfield. J. S. \& Kern, F. (1968). Exp. Mol. Path. 8, 66.

Hopper, A. F., Rose, P. N. \& Wannemacher, R. W. (1972). J. Cell Biol. 53, 225.

Husain, R. \& Syme, G. (1980a). Proc. int. Union Physiol. Sci. 14, 482.

Husain, R. \& Syme, G. (1980b). J. Physiol., Lond. 302, 12P.

Kapadia, S. \& Baker, S. J. (1976). Digestion 14, 256.

Kern, F., Prosper, J. \& Murray, R. (1966). Fedn Proc. Fedn Am. Socs exp. Biol. 25, 322.

Kumar, V. \& Chase, H. P. (1972). Am. J. clin. Nutr. 25, 485.

Sokal, R. R. \& Rohlf, F. J. (1969). Biometry, The Principles and Practice of Statistics in Biological Research, p. 224. San Francisco: W. H. Freeman \& Co.

Stanfield, J. P., Hutt, M. S. R, \& Tunnicliffe, R. (1965). Lancet ii, 519.

Stead, R. H. \& Brock, J. F. (1972). J. Nutr. 102, 1357.

Subramoniam, A. (1979). Acta anat. 104, 439.

Syme, G. \& Smith, M. W. (1982). Cell Biol. Int. Reports (In the Press.)

Warner, R. G. (1962). Publs natl Acad. Sci. no. 990, p. 51.

Whitehead, R. G., Coward, W. A. \& Lunn, P. G. (1973). Lancet i, 63.

Wimber, D. R. \& Lamberton, L. F. (1963). Radiat. Res. 18, 137. 